\title{
Direct TAXation IN THE EU: THE COMMON CORPORATE TAX BASE AS THE NeXT SUb-STEP TOWARDS HARMONIZATION
}

\author{
NORBERT HERZIG AND JOHANNES KUHR*
}

\section{INTRODUCTION}

On 16 March 2011, Algirdas Semeta, the Commissioner for Taxation and Customs Union, presented to the public a proposal for a Council directive on a Common Consolidated Corporate Tax Base (CCCTB). ${ }^{1}$ The CCCTB project has been one of the Commission's political aims since 2001, when it issued a communication to the Council, the Parliament and the Economic and Social Committee on an "internal market without tax obstacles", ${ }^{2}$ which accompanied a comprehensive study by the Commission's services on "company taxation in the internal market". ${ }^{3}$ In 2004, the CCCTB Working Group was established. ${ }^{4}$ As a result of the group's work, more than 60 working papers on technical elements of the CCCTB were published on the Commission's website, ${ }^{5}$ laying the groundwork for the final proposal. ${ }^{6}$

The co-existence of twenty-seven direct tax regimes is seen as one of the major trade barriers still left in the EU. ${ }^{7}$ Yet little progress has been made

DOI: $10.2478 /$ wrlae-2013-0024

* Prof. Dr. Norbert Herzig and Dipl.-Kfm. Johannes Kuhr, University of Cologne; herzig@wiso.uni-koeln.de

${ }^{1}$ European Commission, 'Proposal for a Council Directive on a Common Consolidated Corporate Tax Base' COM (2011) 121/4

${ }^{2}$ European Commission, 'Towards an Internal Market without Tax Obstacles - A strategy for providing companies with a Consolidated Corporate Tax Base for their EU-wide activities' COM (2001) 582 final.

${ }^{3}$ European Commission, 'Company Taxation in the Internal Market' (Commission Staff Working Paper) SEC (2001) 1681.

${ }^{4}$ The CCCTB working group comprises representatives from all member states and is chaired by the Commission (Parillo, 'The CCCTB - Where Are We Now?' [2011] Tax Notes International 471.

$<\mathrm{http}$ ://ec.europa.eu/taxation_customs/taxation/company_tax/common_tax_base/index_en. htm>, accessed 16 January 2012.

6 See Förster, Krauß, 'Der Richtlinienvorschlag der Europäischen Kommission zur Gemeinsamen konsolidierten Körperschaftsteuer-Bemessungsgrundlage (GKKB) vom 16.3.2011' [2011] Internationales Steuerrecht 607.

${ }^{7}$ Munin, 'Tax in Troubled Time: Is It the Time for A Common Corporate Tax Base in the EU?' [2011] EC Tax Review 121. 
when it comes to harmonization in the arena of direct taxation. ${ }^{8}$ Exceptions though limited in scope - are, for example, the Parent-Subsidiary Directive, ${ }^{9}$ the Merger Directive ${ }^{10}$ and the Interest and Royalties Directive. ${ }^{11}$ Furthermore, the European Court of Justice has exerted some indirect pressure on member states to harmonize their different corporate tax systems by eliminating their discriminatory aspects. ${ }^{12}$ The current CCCTB proposal tries to overcome this trade barrier in a single blow. ${ }^{13}$ The approach follows a three-step process. ${ }^{14}$ First, the tax base of European companies is determined by a single set of rules. Second, the amount of taxable profits of corporate groups is reached by consolidating the tax bases of the individual group members. Third, the overall profits are allocated to those member states in which the group is active. Here, the allocated profits are taxed at national tax rates. The allocation mechanism is based on a fixed apportionment formula. Thus, the CCCTB would - at least within the EU: reduce compliance costs for taxpayers; increase transparency; eliminate the problem of international double taxation and non-taxation (due to divergent qualifications and the troublesome documentation of transfer prices); make possible cross-border loss offsetting; and simplify cross-border restructuring. ${ }^{15}$ Nevertheless, political support for the project in member states is low. This article analyses a Common Corporate Tax Base (CCTB), which is to say, a common set of rules for determining the tax base that functions as an interim alternative to a CCCTB without the need for consolidation and formula apportionment. At a later date, the common tax base can be supplemented by the second and third steps described above. ${ }^{16}$

\section{ARguMENTS IN FAVOUR OF A CCTB AND AGAINST CONSOLIDATION}

\section{A. Political feasibility}

Since all decisions concerning direct taxes at EU level generally require a unanimous vote ${ }^{17}$ - any member state can veto the adoption of the CCCTB proposal - it is not likely that the "full package" of its provisions will

\footnotetext{
${ }^{8}$ See Vascega, Thiel van, 'The CCCTB Proposal: The Next Step towards Corporate Tax Harmonization in the European Union?' [2011] European Taxation 374.

${ }^{9}$ Council Directive 90/436/EEC [1990].

${ }^{10}$ Council Directive 90/434/EEC [1990].

${ }^{11}$ Council Directive 2003/49/EC [2003].

12 See Rödder, 'Wo steht und wohin entwickelt sich das Europäische Unternehmenssteuerrecht?' in Kessler, Förster, Watrin (eds), Festschrift Herzig (C.H. Beck 2010) $352 \mathrm{ff}$.

${ }^{13}$ Herzig, 'Vorschlag einer GKKB-RL - ein ambitioniertes Zukunftsprojekt' [2011] Der Betrieb M1.

${ }^{14}$ See Kahle, Dahlke, Schulz, 'Der EU-Richtlinienvorschlag zur CCCTB - Anmerkungen aus Theorie und Praxis' [2011] Die Unternehmensbesteuerung 491.

15 See Rödder, Wo steht und wohin entwickelt sich das Europäische Unternehmenssteuerrecht?' (n 12) 359.

16 See Herzig, Stock, 'Entwicklungen der Organschaft und Zukunftsperspektiven einer Gruppenbesteuerung' [2011] Betriebswirtschaftliche Forschung und Praxis 478ff.

17 Art. 115 TFEU (OJ C115/47), Art. 5 para. 1 TEU (OJ C115/1).
} 
come into effect soon. ${ }^{18}$ In particular, this supposition is supported by the results of the subsidiarity and proportionality test outlining member states' opposition to the CCCTB proposal. ${ }^{19}$ In fact, nine National Parliaments reacted swiftly (the lower house of the Czech Parliament belatedly) to the adoption of the proposal by the Commission and sent their reasoned opinions of the proposal's non-compliance with the principles of subsidiarity ${ }^{20}$ and proportionality $^{21} .^{22}$ This group included Bulgaria, Ireland, Malta, the Netherlands, Poland, Romania, Slovak Republic, Sweden and the United Kingdom. ${ }^{23}$ Concerning their subsidiarity claim, they argue that the Commission failed to provide sufficient quantitative and qualitative evidence showing that member states were unable to remove fiscal impediments to cross-border activity on their own and that action at the EU level was necessary. ${ }^{24}$ They hint at the additional compliance costs for businesses and administrative costs for member states that would come along with the introduction of an optional CCCTB, adding a $28^{\text {th }}$ domestic corporate tax system. Furthermore, they also claim that the proportionality principle has been violated. In their opinion, bilateral and unilateral measures, as well as informal coordination, suffice in addressing cross-border tax problems. Other member states disapprove of at least some parts of the CCCTB proposal. Among those are Belgium, France, Italy, Lithuania and Germany. ${ }^{25} \mathrm{~A}$ way to circumvent the unanimity requirement of Art. 115 TFEU as the legal basis for the proposal is through the enhanced cooperation of a smaller group of interested member states. However, the utilization of this instrument is in turn subject to a range of conditions not easily met. ${ }^{26}$ What's more, if several member states decide to move forward under the Lisbon Treaty articles on enhanced cooperation, it is more likely that they will attempt to introduce a CCTB in lieu of a CCCTB. The reason for this lies first and foremost in budgetary concerns. ${ }^{27}$ Many member states fear a loss in tax revenues because of a bias in the consolidation and formula apportionment mechanism. Since intangible and financial assets are excluded from the formula, states with large service industries were put at a disadvantage, while those with labourintensive economies reap additional benefits. For instance, the Federal Government of Germany rejects a CCCTB, but welcomes a CCTB. ${ }^{28}$ On 16 August 2011 French President Nicolas Sarkozy and German Federal Chancellor Angela Merkel announced at a meeting in Paris that both states

\footnotetext{
18 See Rödder, 'Einführung einer neuen Gruppenbesteuerung an Stelle der Organschaft' [2011] Die Unternehmensbesteuerung 489.

${ }^{19}$ See Vascega, Thiel van (n 8) $377 \mathrm{ff}$.

${ }^{20}$ Art. 5 para. 3 TEU.

${ }^{21}$ Art. 5 para. 4 TEU.

${ }^{22}$ The opinions can be retrieved from the inter-parliamentary EU information exchange system, available at $<\underline{\text { http://www.ipex.eu/IPEXL-WEB/home/home.do }}>$ accessed 16 January 2012.

${ }^{23}$ For a detailed account of the individual opinions of the National Parliaments see Brocke von, Rottenmoser, 'Harmonisierung direkter Steuern? Die GKKB im Lichte der Rechtsetzungskompetenzen der EU' [2011 ] Internationale Wirtschaftsbriefe 620ff.

${ }^{24}$ See Vascega, Thiel van (n 8) 378.

${ }^{25}$ Brocke von, Rottenmoser (n 23) 623.

${ }^{26}$ Vascega, Thiel van (n 8) 381.

27 ibid 380.

${ }^{28}$ See Bundestags-Drucksache $17 / 5748$ of 5 May 2011, 2.
} 
intend to introduce a common set of rules to determine the tax base by the year 2013. ${ }^{29}$ Although some of the main objectives of the CCCTB project were not achieved this way - e.g. the elimination of the transfer pricing procedures, cross-border loss offsetting and simplification of cross-border restructuring - there would still be a worthwhile decrease in compliance and administrative costs, enhanced transparency concerning international investments and a disappearance of international double taxation and nontaxation due to divergent qualifications. ${ }^{30}$

\section{B. Unitary taxation as a panacea? Some caveats}

Political feasibility is not the only thing that speaks against a CCCTB and for a CCTB; there is a range of other considerations as well. In fact, it is likely that international tax planning under a formula apportionment regime will only shift from transfer pricing to a tax-optimal geographic allocation and the manipulation of formula factors; ${ }^{31}$ this is especially likely if national tax rates differ significantly, as intended by the CCCTB proposal. ${ }^{32}$ Economic distortions and perceptions of unfairness will be the consequence, ${ }^{33}$ all the more so when the same formula is applied to all industries. ${ }^{34}$ It is very doubtful that factors can be selected to adequately represent the generation of income - factors that are under the influence of the taxpayer, but at the same time neither distort economic decisions nor are prone to manipulation. ${ }^{35}$ The formula of the CCCTB proposal relies on three equally weighted microeconomic factors: labour ${ }^{36}$, assets ${ }^{37}$ and sales ${ }^{38} .{ }^{39}$ Each of these is susceptible to manipulation. ${ }^{40}$ The labour factor could either be influenced by actively managing the exclusion or inclusion of the work force into the factor or by governing the geographical distribution of the work force. The capital factor is particularly vulnerable to manipulation of reference date, i.e. shifting parts of the tax base to low-tax member states by selling or purchasing assets within the group prior to the end of the tax year. The degree to which the sales factor

${ }^{29}$ Berschens, Hoppe, 'Merkel und Sarkozy - einig wie nie' Handelsblatt (Düsseldorf, 17 August 2011) 12.

${ }^{30}$ Herzig, Stock ( 16) 479; Mintz, 'Corporate Tax Harmonization in Europe: It's All About Compliance' [2004] International Tax and Public Finance $221 \mathrm{ff}$.

${ }^{31}$ See Oestreicher, 'Konzernbesteuerung in Europa - Zum Vorschlag einer konsolidierten körperschaftsteuerlichen Bemessungsgrundlage für die grenzüberschreitende Unternehmenstätigkeit in der EU' [2011] Steuer und Wirtschaft 354.

${ }^{32}$ See CCCTB proposal (n 1), art. 103.

33 Weiner, 'The European Union and Formula Apportionment: Caveat Emptor' [2011] European Taxation 381.

34 The apportionment formula of the CCCTB proposal (n 1) accounts for the specifics of some industries (see arts. 98-101).

35 Herzig, Teschke, Joisten, 'Between Extremes: Merging the Advantages of Separate Accounting and Unitary Taxation' [2010] Intertax 334.

${ }^{36}$ The labour factor is split equally between payroll costs and the number of employees (CCCTB proposal (n 1), art. 90, para 1).

37 The asset factor consists of all fixed tangible assets owned, rented or leased by a group member; as a proxy for intangible assets, $\mathrm{R} \& \mathrm{D}$, marketing and advertising costs in the six years prior to a company entering into the CCCTB are also to be included for five years (CCCTB proposal, art. 92).

${ }^{38}$ The sales factor includes the proceeds of all sales of goods and supplies of services after discounts and returns (CCCTB proposal, art. 95, para. 2).

${ }^{39}$ ibid, art. 86.

${ }^{40}$ See Herzig, Teschke, Joisten (n 35) 339ff. 
can be manipulated depends on whether sales are recorded at destination or origin as it is more difficult to manipulate the country of destination than the country of origin. Needless to say, the CCCTB proposal contains a catalogue of countermeasures to prevent this kind of manipulation. For instance, the labor factor includes employees who, although not employed directly by a group member, perform tasks similar to those performed by direct employees. ${ }^{41}$ Likewise, assets are computed as an average. ${ }^{42}$ Sales are recorded at destination. ${ }^{43}$ Nonetheless, precautions and anti-abuse rules like these increase complexity and will probably not be an airtight guarantee against manipulation, always leaving some leeway for tax planning. Hence, member states cannot be criticized for taking a "buyer beware approach" to formula apportionment. ${ }^{44}$

\section{The CCCTB Proposal: COMMON TAX BASE}

\section{A. No linkage to financial accounting}

The CCCTB proposal defines the tax base completely on its own. ${ }^{46}$ In spite of the huge array of literature on aligning financial and tax accounting that has been published during the last decade,${ }^{47}$ it depends neither on a formal linkage nor on any other reference to national GAAP or IFRS / IAS. ${ }^{48}$ Whilst reference to local GAAP had the advantage that recourse could be taken to already existing legislature and jurisprudence, a fragmentation of the tax base into 27 single systems would almost inevitably be the consequence, and

${ }^{41}$ CCCTB proposal (n 1), art. 91 para. 3.

42 ibid, art. 94.

${ }^{43}$ According to art. 96 para. 1 CCCTB proposal, sales of goods shall be included in the sales factor of the Member State where dispatch or transport of the goods to the person acquiring them ends.

${ }^{44}$ Weiner (n 33) 381.

45 For a detailed discussion see Herzig, Kuhr, 'Grundlagen der steuerlichen Gewinnermittlung nach dem GKKB-Richtlinienentwurf’ [2011] Der Betrieb 2053ff.

${ }^{46}$ Marx, 'Die Gewinnermittlungskonzeption der GKKB nach dem Richtlinienentwurf der EU-Kommission' [2011] Deutsche Steuerzeitung 550.

47 See for example Macdonald, 'The Taxation of Business Income - Aligning Taxable Income with Accounting Income' (2002) TLRC Discussion Paper No. 2 $<$ http://www.ifs.org.uk/comms/dp2.pdf $>$ accessed 16 January 2012; Schneider, 'Problemfelder und Methoden des Rechnungswesens allgemein und einer Konzernrechnungslegung als international Gewinnsteuerbemessungsgrundlage im Besonderen' [2003] Betriebswirtschaftliche Forschung und Praxis 652ff; Herzig, Gellrich, Jensen, Nissen, 'IAS/IFRS und steuerliche Gewinnermittlung' [2004] Betriebswirtschaftliche Forschung und Praxis 550ff; Freedman, 'Aligning Taxable Profits and Accounting Profits' (2004) 2 no.1 eJournal of Tax Research $71 \mathrm{ff}$. $<$ http://denning.law.ox.ac.uk/tax/documents/Freedman-

Aligning taxable profitsEjournal.pdf $>$ accessed 16 January 2012; Herzig, 'IAS/IFRS und steuerliche Gewinnermittlung' [2005] Die Wirtschaftsprüfung (WPg) 211ff; Mössner, 'Internationale Rechnungslegung und steuerliche Gewinnermittlung' in Ebke et. al. (eds), Internationale Rechnungslegungsstandards für börsenunabhängige Unternehmen? (Nomos 2007) 165ff; Freedman, 'Financial and Tax Accounting' in Schön (ed), Tax and Corporate Governance (Springer 2008) $71 \mathrm{ff}$.

48 Scheffler, Krebs, 'Richtlinienvorschlag zur CCCTB, Bestimmung der Steuerbemessungsgrundlage im Vergleich mit der Steuerbilanz nach EstG' [2011] Deutsches Steuerrecht (Beihefter zu Heft 22) 14ff. 
would thwart the aim of harmonization. ${ }^{49}$ Therefore, such an approach should be rejected when simplification through harmonization is the main goal, as is the case with a CCTB. Although IFRS / IAS would provide a common reference point, they must be excluded for various other reasons ${ }^{50}$ For starters, the vast majority of European companies do not draw up annual IFRS / IAS accounts, particularly small and medium-sized enterprises (SME). ${ }^{51}$ For these companies, it would probably be easier to adopt an entirely new tax base like the one outlined in the CCCTB proposal than to adjust to the complex system of IFRS / IAS ${ }^{52}$ In addition, the possibility of a private standardsetting body having an indirect effect on the tax base despite the comitology procedure clashes with the rule of law and the principle of democracy. ${ }^{53} \mathrm{In}$ similar fashion, the divergent goals of the IFRS / IAS and taxation seem irreconcilable. ${ }^{54}$ Finally, and in the interest of IFRS / IAS themselves, the "tax pollution" of financial accounting should be fended off. ${ }^{55}$ In conclusion, it is to be welcomed that the CCCTB proposal only bespeaks of an adoption of IFRS / IAS ideas deemed by the European Commission to be in line with the goals of the project: financial assets and liabilities held for trading (Art. 23), long-term contracts (Art. 24), provisions (Arts. 25, 26) and accounting for leases (Art. 36). ${ }^{56}$

\section{B. Profit and loss approach}

According to Art. 10 of the CCCTB proposal, the tax base is calculated as the difference between taxable revenues and deductible expenses as well as other deductible expenses. In accordance with Art. 17, revenues, deductible expenses and other deductible expenses shall in general be recognized when they accrue or are incurred. Two important conclusions can be drawn from this. First, profits are not determined on a cash basis. ${ }^{57}$ Instead there is a clear commitment to the accrual principle. ${ }^{58}$ Second, the Commission chose the profit and loss approach over the balance sheet method. ${ }^{59}$ The latter calculates taxable income by comparing the value of the assets in the balance sheet at the end of the period - plus dividends distributed

\footnotetext{
${ }^{49}$ Spengel, Malke, 'Comprehensive Tax Base or Residual Reference to GAAP or Domestic Tax Law?' in Lang, Pistone, Schuch, Staringer (eds), CCCTB (Linde 2008) 87.

50 See also Kahle, Schulz, 'Harmonisierung der steuerlichen Gewinnermittlung in der Europäischen Union' [2011] Betriebswirtschaftliche Forschung und Praxis 461ff.

51 CCCTB Working Group, 'CCCTB: possible elements of a technical outline' CCCTB/057/doc/en of 26 July 2007, 5.

52 Mors, Rautenstrauch, 'Die GKKB als harmonisiertes Körperschaftsteuerrecht der Zukunft' [2008] Die Unternehmensbesteuerung 98.

53 See Herzig, Bär, 'Die Zukunft der steuerlichen Gewinnermittlung im Licht des europäischen Bilanzrechts', [2003] Betriebs-Berater 4

54 See Fülbier, 'Systemtauglichkeit der International Financial Reporting Standards für Zwecke der steuerlichen Gewinnermittlung' [2006] Steuer und Wirtschaft 236ff.

55 See Schön, "International Accounting Standards - A "Starting Point" for a Common European Tax Base?' [2004] European Taxation 429ff.

${ }^{56}$ Prinz, 'Richtlinienvorschlag der EU - Das europäische GKKB-Projekt - eine Einschätzung aus Beratersicht' [2011] Steuer und Bilanzpraxis 463.

${ }^{57}$ Scheffler, Krebs (n 48) 15.

${ }^{58}$ See also CCCTB proposal (n 1), arts 18-19.

${ }^{59}$ For an introduction into the concept of the tax balance sheet see CCCTB Working Group, "Concept of the "tax balance sheet" CCCTB/WP/16/doc/en of 7 September 2005. See also Schön (ed), Steuerliche Maßgeblichkeit in Deutschland und Europa (Verlag Dr. Otto Schmidt 2005).
} 
by the taxpayer and minus increases in capital during the year - with the value of net assets in the balance sheet at the end of the previous year. ${ }^{60}$

Both approaches, the profit and loss technique and the balance sheet method, are in many respects similar and lead ceteris paribus to the same results. However, the balance sheet method usually starts with the financial accounts balance sheet, whereas the profit and loss method supposedly either uses the profit and loss account as a starting point or calculates revenues and expenses directly for tax purposes. ${ }^{61}$ Although the tax base of the CCCTB proposal could in theory be calculated independently from financial accounting, in practice it is very likely that the balance sheet as well as the profit and loss account will serve as a starting point. ${ }^{62}$ This assumption can be corroborated by an examination of the CCCTB proposal's explicit and implicit documentation requirements, to whose fulfillment especially the financial account balance sheet lends itself as a starting point. ${ }^{63}$ For example, costs relating to acquisition, construction or improvement are not deductible in the year the asset is acquired, constructed or improved. Instead, only a proportional deduction may be made in respect of the depreciation of fixed assets $^{64}$ and costs related to non-depreciable assets are generally only deductible in the tax year in which the assets are disposed of. ${ }^{65}$ These costs must thus be recorded. ${ }^{66}$ Concerning stocks and work-in-progress, deductible expenses for a tax year shall be increased by the value of stocks and work-inprogress at the beginning of the tax year and reduced by the value of those at the end of the same tax year. ${ }^{67}$ This way, the expenses relating to stocks and work-in-progress are only deductible when the latter are sold or used, again requiring an auxiliary calculation. Moreover, the same also applies to the simulation of the expense impact of provisions by Art. 25 of the CCCTB proposal. ${ }^{68}$ Finally, it should be noted that the proposal tries to cover every aspect of the tax base, ${ }^{69}$ which means that there are many tax-specific provisions necessitating modifications when adopting results from financial accounting. This includes rules on exempt revenues (Art. 11), non-deductible expenses (Art. 14), expenditure incurred for the benefit of shareholders (Art. 15), transactions between associated enterprises (Arts. 78-79) as well as anti-abuse rules (Arts. 80-83).

\section{Role of principles}

At one of the initial meetings of the CCCTB Working Group a working paper titled "General Tax Principles" was presented and discussed. ${ }^{70}$

\footnotetext{
${ }^{60}$ CCCTB Working Group, 'Taxable income' CCCTB/WP/17/doc/en of 7 September 2005, 3.

${ }^{61}$ ibid.

${ }^{62}$ Prinz, 'Richtlinienvorschlag der EU - Das europäische GKKB-Projekt - eine Einschätzung aus Beratersicht' [2011] Steuer und Bilanzpraxis 463.

${ }^{63}$ See also Marx (n 46) 547.

${ }^{64}$ CCCTB proposal (n 1), arts 13, 32-42.

65 ibid, art. 20.

66 Together with the relevant date (ibid, art 32).

${ }^{67}$ ibid, art. 21.

${ }^{68}$ More precisely: CCCTB proposal, art. 25, para 1 (3).

${ }^{69}$ Vascega, Thiel van (n 8) 376.

${ }^{70}$ CCCTB Working Group, 'General Tax Principles' CCCTB/WP/001Rev1 \doclen of 10 December 2004
} 
It outlined a wide range of general principles for the design and assessment of tax systems as well as specific tax accounting principles. At that time, the Working Group had decided to take an "informal approach" on this matter and not to formulate a catalogue of tax principles. ${ }^{71}$ Later experts became uneasy when they realized that, without a minimum level of tax principles, countries would resort to the national GAAP whenever CCCTB legislation was incomplete or unclear. ${ }^{72}$ This led to the insertion of Art. 9, which contains general tax principles to assist in the interpretation of the CCCTB proposal and to eliminate the need for national legislation and legal practice. Whether the four principles of Art. 9 - the realization principle, the individual measurement of transactions and taxable events, consistency in the calculation of the tax base, the concept of tax years - can live up to these expectations remains to be seen. Principles play such a crucial role in achieving the goal of harmonization since a European Tax Court is not envisioned by the CCCTB proposal and common rules will be of no avail if their interpretation differs considerably under the auspices of national judges and tax inspectors. ${ }^{73}$ The analysis of the extent to which overarching unwritten principles can be derived from the detailed rules of the proposal is at any rate an avenue for future research. ${ }^{74}$

\section{OTHER ASPECTS OF THE PROPOSAL IN LIGHT OF A CCTB WITHOUT CONSOLIDATION}

\section{A. Optionality \& personal scope}

Art. 6 of the proposal stipulates that the application of the CCCTB is optional. ${ }^{75}$ Once the system has been successfully opted into, it has to be applied for a minimum period of five tax years. ${ }^{76}$ On closer inspection one can find a multitude of pros and cons regarding optionality when discussing a CCCTB as well as a CCTB. ${ }^{77}$ However, the balance between those arguments might change in light of a CCTB without consolidation and formula apportionment compared with a CCCTB. Whilst the CCCTB proposal provides optionality, the federal government of Germany for instance favours a CCTB that is mandatory. ${ }^{78}$ The list of pros and cons of optionality can be divided into the positive and negative arguments that hold true for both a CCCTB and a CCTB and those that differ on this point. To the former group belongs the following line of argumentation. ${ }^{79}$ Optionality minimizes the risk of a non-competitive system ${ }^{80}$ and it prevents the drifting

71 CCCTB Working Group, 'Progress to date and future plans for the CCCTB' CCCTB/WP/020/doc/en of 15 November 2005, 5 .

72 CCCTB Working Group, 'Various detailed aspects of the CCCTB' CCCTB/WP/066/doc/en of 27 March 2008, 2.

${ }^{73}$ Schön (n 55) 429.

${ }^{74}$ Insofar pessimistic: Marx (n 46) 550.

${ }^{75}$ See Kahle, Dahlke, Schulz (n 50) 592.

${ }^{76}$ CCCTB proposal, art 105, para. 1.

${ }^{77}$ The considerations of this subsection are based on Hey, 'CCCTB - Optionality' in Lang, Pistone, Schuch, Staringer (eds), CCCTB (Linde 2008) 93ff.

${ }^{78}$ See Bundestags-Drucksache 17/5748 of 5 May 2011, 1.

${ }^{79}$ See Hey (n 77) $102 \mathrm{ff}$.

${ }^{80}$ Since national systems would have to compete against the CCCTB/CCTB and vice versa. 
apart of the domestic tax base and the CCCTB / CCTB. ${ }^{81}$ Furthermore, change is less fundamental and national sovereignty is not as severely restricted as compared with a mandatory CCCTB / CCTB ${ }^{82}$ SMEs in particular can avoid complications. Speaking against optionality are the high compliance costs of exercising the option, ${ }^{83}$ the administrative burden ${ }^{84}$ and opportunities for shopping between the two systems. ${ }^{85}$ To the latter group belong the following arguments. On the one hand, the positive argument that an optional system avoids the necessity of an opening clause to the formula apportionment procedure holds true only for a CCCTB since a CCTB does not feature formula apportionment. ${ }^{86}$ On the other hand, the negative arguments that optionality would perpetuate profit-shifting opportunities ${ }^{87}$ and increase the budget risks of cross-border consolidation ${ }^{88}$ are likewise applicable only to a CCCTB and not to a CCTB. ${ }^{89}$ Furthermore, the above arguments have to be weighted differently depending on whether optionality is evaluated with regard to a CCCTB or a CCTB regime. While with a CCCTB it might be argued that the strongest argument against optionality is the elimination of profit shifting and that the compliance costs issue does not weigh as heavily in comparison, ${ }^{90}$ the optionality of a CCTB seems out of the question precisely due to the fact that this is the only way compliance costs can be reduced significantly, which is after all the main goal of a CCTB.A question closely related to optionality is the personal scope of a CCCTB / CCTB. ${ }^{91}$ As its name suggests, the proposed CCCTB is limited to entities that are subject to corporate tax law, thus excluding partnerships that are flowthrough entities. ${ }^{92}$ Henceforth, the system is not neutral regarding legal form. If it were mandatory, the only way out for companies would be to reorganize into partnerships. Even though this appears at first glance as a strong

${ }^{81}$ This seems especially important when considering that at least according to the CCCTB proposal partnerships would not be eligible for a CCCTB/CCTB.

${ }_{82}$ Nevertheless, member states could not prevent companies from opting for the new system.

${ }^{83}$ A CCCTB / CCTB would add the $28^{\text {th }}$ system to the already existing 27 national ones. Taxpayers would face the highly complex decision whether they should opt or not.

84 The option requirements as well as the changes between systems would have to be controlled by tax authorities. Moreover, two sets of rules would have to be applied at the same time.

${ }^{85}$ Although the five year minimum period hampers constant opting in and out and under a CCTB regime the opportunity of shopping between the national GAAP and the CCTB would not include the choice between unitary accounting and separate entity accounting as is the case with a CCCTB but be confined to a choice between two sets of rules determining the tax base.

${ }^{86}$ However, the CCCTB proposal even contains an opening clause for cases where the application of the formula leads to an unreasonable allocation of the group's profits (Art. 86) although the regime would be optional.

${ }^{87}$ A mandatory CCCTB would eliminate the problem of transfer price tax planning within the EU since intra-group transactions would be eliminated by means of consolidation, whereas an optional CCCTB would still leave the taxpayer with the choice to stick to separate entity accounting.

${ }^{88}$ Taxpayers for which the CCCTB is advantageous will opt and those for which it is not will refrain from opting.

${ }^{89}$ Hey (n 77) 104ff, 108.

${ }^{90}$ ibid 111.

91 ibid $100 \mathrm{ff}$.

${ }^{92}$ CCCTB proposal, art. 1-3, Annexes I, II. Also see Staringer, 'Requirements for Forming a Group' in Lang, Pistone, Schuch, Staringer (n 77) $120 \mathrm{ff}$. 
argument for an optional system that reduces such distortions, ${ }^{93}$ only a mandatory system is capable of truly reducing compliance costs. In order to avoid distortions - and also the administrative burden of applying two systems at the same time - the personal scope of a compulsory CCTB would therefore have to include partnerships as flow-through entities, ${ }^{94}$ creating a "Common Entrepreneurial Tax Base" (CETB) or something similar. ${ }^{95}$

\section{B. Methods and scope of consolidation}

The tax-specific consolidation technique of the CCCTB proposal abandons three out of the four financial accounting consolidation methods. ${ }^{96}$ Since the tax base envisaged by the proposal is based on the profit and loss approach, capital consolidation, debt consolidation as well as consolidation of expenses and income do not apply. ${ }^{97}$ Only profits and losses arising from intra-group transactions have to be eliminated, which allows cross-border losses to be offset and disarms the explosiveness of transfer pricing. ${ }^{98}$ Even though a CCTB or a CETB does not provide these advantages, intra-group profit and loss elimination should still apply within the framework of a national group taxation system. This is because intra-group transfers of goods and provisions of services should not have an impact on the overall amount of taxable profits since the associated profits and losses have yet to be realized. The realization principle requires that goods or services already be transferred to the market. ${ }^{99}$ According to the CCCTB proposal, a resident taxpayer forms a group with all its qualifying subsidiaries and permanent establishments located in a EU Member State. ${ }^{100}$ This is often referred to as "all-in-or-all-out" principle, which is designed to forestall cherry picking. ${ }^{101}$ Territorially, the scope of consolidation is limited to the "water's edge", that is, third-party countries are not included. ${ }^{102}$ Qualifying subsidiaries are all immediate and lower-tier subsidiaries of whose voting rights the parent company has the right to exercise more than $50 \%$ and with reference to which the parent company owns more than $75 \%$ of the capital or the rights giving entitlement to profit. ${ }^{103}$ The CCCTB proposal's definition of the consolidation scope is based exclusively on legal criteria. ${ }^{104}$ Indeed, economic criteria were

\footnotetext{
${ }^{93}$ Hey (n 77) 100ff.

${ }^{94}$ For example, the Federal Council of Germany favours an inclusion of all partnerships in the personal scope of a CCCTB (Bundesrat-Drucksache 155/11(B)(2) of 17 July 2011, p. 1). In Germany, most business enterprises have the legal form of a partnership.

${ }^{95}$ Herzig, 'Vorschlag einer GKKB-RL' (n 13).

${ }^{96}$ See Herzig, 'Tax Harmonization in Europe: Methods of Consolidation' in Lang, Pistone, Schuch, Staringer (n 77) 556.

${ }^{97}$ See Kahle, Dahlke, Schulz (n 50) 497ff.

${ }^{98}$ CCCTB proposal (n1), art. 59.

${ }^{99}$ See Kahle, Dahlke, Schulz (n 50) 498.

${ }^{100}$ CCCTB proposal (n 1), art. 55.

101 Since the taxpayer can only opt into the system together with all of its qualifying subsidiaries and permanent establishments within the EU and not just together with those for whom the application of the system is advantageous (Kußmaul, Niehren, 'Die Gemeinsame Konsolidierte Körperschaftsteuer-Bemessungsgrundlage in der Europäischen Union’ [2011] Der Steuerberater 346).

102 Herzig, Teschke, Joisten (n 35) $341 \mathrm{ff}$.

${ }^{103}$ CCCTB proposal (n 1), art. 54.

${ }^{104}$ Kahle, Dahlke, Schulz (n 50) $498 f f$.
} 
left out of consideration by the CCCTB Working Group. ${ }^{105}$ The decision for legal thresholds for consolidation clearly comes with the advantage of administrative simplicity. ${ }^{106}$ Yet it poses the problem of manipulation. Integration of a given entity into a CCCTB group could be actively governed by manipulating the legal consolidation thresholds, depending on whether a higher portion of profit could be shifted to low-tax jurisdictions by either formula allocation or manipulation of transfer prices. While economic criteria might be less vulnerable to consolidation, their downside is that they are to a certain degree subjective, possibly giving rise to a conflict between taxpayers and tax authorities and thereby resulting in administrative complexity. ${ }^{107}$ Naturally, this quandary is avoided completely by a mandatory CCTB / CETB. ${ }^{108}$

\section{Formula apportionment \& one-stop shop}

Some of the drawbacks of formula apportionment were touched upon above when it was questioned whether unitary taxation was indeed a panacea. In addition to the problem of its vulnerability to tax planning and its likeliness to trigger economic distortions, one of the major challenges of gaining political support for a CCCTB after introducing a CCTB / CETB lies in finding a formula that is perceived as balanced and fair by the member states, industries and taxpayers alike. While a one-factor formula might be easier to manage, the three-factor model chosen in Art. 86 of the CCCTB proposal reflects the generation of income more adequately. ${ }^{109}$ However, the weighting as well as the design of labour, asset and sales factors will probably be put to further discussion. For instance, a complaint often voiced is that the exclusion of intangible and financial assets puts member states with large service industries and high levels of productivity at a disadvantage, whereas labourintensive economies would benefit unduly. ${ }^{110}$ If the four industry-specific apportionment mechanisms contained in the proposal - regarding financial institutions, insurance undertakings, oil and gas as well as shipping and air transport - suffice to meet such concerns is doubtful. ${ }^{111}$ Furthermore, the CCCTB proposal is based on the concept of a one-stop shop. ${ }^{112}$ According to this concept, the principal member of a group performs all administrative procedures on behalf of the whole group with its own tax authority. ${ }^{113}$ This ranges from the notice to opt for the CCCTB regime (Arts. 104, 105) and the filing of the tax return (Arts. 109, 112) to the assessment by the tax authority (Arts. 112, 114), audits (Art. 112) and appeals (Ars. 124-126). If a CCTB / CETB were introduced, the idea of the one-stop shop for a EU-wide group

\footnotetext{
105 See Herzig, Teschke, Joisten (n 35) 337.

${ }^{106}$ Andersson, 'An Optional CCCTB for the European Union' in Andersson, Eberhartinger, Oxelheim (eds), National Tax Policy in Europe. To Be or Not to Be? (Springer 2007) 109.

${ }^{107}$ See Herzig, Teschke, Joisten (n 35) 337.

${ }^{108}$ Under an optional CETB regime, the integration of an entity into the group (admittedly only within the framework of a national group taxation system) would probably still be manipulated depending on whether the national or the CETB's set of rules for determining the tax base is beneficial for the specific entity in question.

${ }^{109}$ Kahle, Dahlke, Schulz (n 50) 500.

${ }^{110}$ Vascega, Thiel van (n 8) 380.

${ }^{111}$ CCCTB proposal (n 1), arts. 98-101.

112 Kahle, Dahlke, Schulz (n 50) 502.

${ }^{113}$ Vascega, Thiel van (n 8) 376.
} 
would have to be put aside for the time being until the supplementation of the CCTB / CETB regime with consolidation and formula apportionment.

\section{CONCLUSIONS}

Two major arguments militate for untying the full package of the CCCTB and focusing on a CCTB / CETB without consolidation and formula apportionment. On the one hand, member states' political support is low, especially for the second and third steps of the project. This is amongst others evidenced by the fact that ten member states sent their reasoned opinions of the proposal's non-compliance with the principles of subsidiarity and proportionality. There are signs, however, that some member states embrace the idea of a CCTB / CETB. On the other hand, formula apportionment is by no means a panacea since profit-shifting by transfer pricing would probably just be substituted by profit-shifting via manipulation of the apportionment formula. Economic decisions are also likely to be distorted under such a regime. Although a CCTB / CETB does not offer all the advantages of a $\mathrm{CCCTB}$, it nevertheless results most notably in a significant reduction of compliance and administrative costs - provided that its application is mandatory and that partnerships as flow-through entities are included in its personal scope. Naturally, the common set of rules for determining the tax base in the CCCTB proposal suggests itself as a point of departure for drafting a CCTB / CETB. The provisions relating to consolidation, formula apportionment and the administrative idea of a one-stop shop will not be adopted for the time being. It is a positive sign that the proposal defines the tax base completely on its own without links to financial accounting, only adopting the ideas of IFRS / IAS when they are deemed by the Commission to be appropriate to the tax-specific goals of the project. In practice, however, it is likely that the financial accounting balance sheet and profit and loss account will serve as an informal starting point for the profit and loss approach chosen in the proposal. Furthermore, it is disputable whether the four principles listed in Art. 9 of the CCCTB proposal will be enough to assist in the interpretation when legislation is incomplete or unclear. For this purpose, overarching unwritten principles might be able to be derived from the detailed rules of the proposal. 